\title{
ANALISIS KELAYAKAN BISNIS RENCANA PENDIRIAN USAHA BUTIK BUSANA LADY CENTER DI PRINGSEWU
}

\author{
ANALYSIS OF BUSINESS FEASIBILITY PLAN FOR THE \\ ESTABLISHMENT OF A BOUTIQUE LADY CENTER IN PRINGSEWU
}

\author{
Sapmaya Wulan', Tya Mei Astuti \\ Fakultas Ekonomi dan Bisnis Universitas Bandar Lampung \\ Jl. Z.A Pagar Alam No.26 Labuhan Ratu Bandar Lampung 35142 Tel. 0721-701979 \\ Email: sapmaya.wulan@ubl.ac.id; Tya.15011041@ student.ubl.ac.id
}

\begin{abstract}
ABSTRAK
Dunia bisnis saat ini berkembang pesat pada kota-kota berkembang maka tidak dapat dipungkiri pula akan berkembangnya bisnis-bisnis yang ada saat ini. Berkembangnya bisnis tersebut dikarenakan banyakanya permintaan konsumen akan kebutuhan yang harus mereka penuhi. Kebutuhan yang semakin meningkat ini tentunya juga memerlukan sarana dan prasarana dalam pendistribusiannya karena tidak semua orang dapat membuat sendiri kebutuhan sandang yang mereka butuhkan oleh sebab itu mulai bermunculan industriindustri dibidang fashion. Butik merupakan toko pakaian ekslusif yang menjual berbagai macam pakaian yang berbeda. Untuk mendirikan Butik Lady Center perlu ada rancangan perkiraan biaya yang diperlukan, modal yang dibutuhkan dan benefit yang akan diperoleh. Sebelum rencana Butik Lady Center dilaksan akan terlebih dahulu perlu dilakukan Analisis Kelayakan Bisnis untuk mengetahui kelayakan usaha tersebut. Untuk itu yang menjadi permasalahan penelitian iniadalah: Apakah rencana mendirikan Butik Lady Center di Pringsewu layak untuk dilaksanakan ? Tujuan penelitian ini adalah untuk mengetahui kelayakan rencana usaha Butik Lady Center di Pringsewu. Penelitian ini menggunakan metode kuantitatif dan kualitatif, dimana untuk metode kuantitatif digunakan tiga Kriteria Investasi yaitu: Net Present Value (NPV), Net Benefit Cost Ratio (Net B/C), Internal Rate of Return (IRR); Analisis Pay Back Period (PBP), dan Analisis Break Even Point (BEP)dan untuk metode kualitatif digunakan pendekatan non-finansial yakni aspek teknis, aspek pasar dan pemasaran, aspek yuridis (hukum), aspek birokrasi, aspek manajemen dan sdm, aspek ekonomis, dan aspek lingkungan. Berdasarkan hasil analisis finansial diperoleh NPV $=\mathrm{Rp}$ 467.412.569; Net $\mathrm{B} / \mathrm{C}=1,19$; IRR $=35,83 \%$, analisis Pay Back Period selama 3 tahun 9 bulan 9 hari, dan analisis Break Even Point selama 3 Tahun 1 Bulan 26 Hari. Berdasarkan hasil analisis kuantitatif dan kualitatif dapat disimpulkan bahwa rencana mendirikan Butik Lady Center layak untuk dilaksanakan $(g o)$.
\end{abstract}

Kata Kunci: Analisis Kelayakan Bisnis, Kriteria Investasi, Pay Back Period, Break Even Point. 


\begin{abstract}
The business world is currently growing rapidly in developing cities, so it cannot be denied that there will be a growing business that exists today. The development of the business is due to the large number of consumer demands for the needs they must fulfill. This increasing need, of course, also requires facilities and infrastructure in its distribution because not everyone can make their own clothing needs that they need because of the start of industries in the field of fashion. Boutique is an exclusive clothing store that sells a variety of different clothing. To establish a Lady Center Boutique there is a need to design a cost estimate, the capital needed and the benefits to be obtained. Before the plan for the Lady Center Boutique is implemented, it will first need to do a Business Feasibility Analysis to determine the feasibility of the business. The problem with this research is this: Is the plan to establish a Lady Center Boutique in Pringsewu feasible?

The purpose of this study was to determine the feasibility of the business plan of the Lady Center Boutique in Pringsewu. This research uses quantitative and qualitative methods, where for quantitative methods three investment criteria are used, namely: Net Present Value (NPV), Net Benefit Cost Ratio (Net B / C), Internal Rate of Return (IRR); Pay Back Period Analysis (PBP), and Break Even Point Analysis (BEP) and for qualitative methods are used non-financial approaches, namely technical aspects, market aspects and marketing, juridical aspects (law), bureaucratic aspects, management aspects and human resources, economic aspects and environmental aspects.

Based on the results of financial analysis, $N P V=R p .467,412,569 ;$ Net $B / C=1.19$; IRR $=$ $35.83 \%$, analysis of Pay Back Period for 4 years 9 months 9 days, and analysis of Break Even Point for 3 years 1 months 26 days. Based on the results of quantitative and qualitative analysis it can be concluded that the plan to establish a Lady Center Boutique is feasible (go).
\end{abstract}

Keywords: Business Feasibility Study, Investment Criteria, Pay Back Period, Break Even Point.

\section{PENDAHULUAN}

Dunia bisnis saat ini berkembang pesat pada kota-kota berkembang maka tidak dapat dipungkiri pula akan berkembangnya bisnis-bisnis yang ada saat ini. Berkembangnya bisnis tersebut dikarenakan banyakanya permintaan konsumen akan kebutuhan yang harus mereka penuhi. Kebutuhan yang semakin meningkat ini tentunya juga memerlukan sarana dan prasarana dalam pendistribusiannya karena tidak semua orang dapat membuat sendiri kebutuhan sandang yang mereka butuhkan oleh sebab itu mulai bermunculan industri-industri dibidang fashion. Saat ini perkembangan fashion di indonesia sudah sangat pesat, yang diikuti dengan tren yang silih berganti. Dampak perkembangan fashion tersebut tentu saja membuat masyarakat mau tidak mau mengikuti tren yang ada. Bahkan bukan hanya sekedar mengikuti tetapi sudah menjadi suatu kebutuhan bagi masyarakat modern saat ini untuk tampil trendy dan stylish. Secara umum trend fashion berkembang sangat cepat terjadi di masyarakat baik masyarakat kota maupun kabupaten. Tak terkecuali di kabupaten pringsewu, berdasarkan pengamatan penulis tentang mode fashion masyarakat dikabupaten pringsewu tidak kalah berkembang dengan mode fashion masyarakat kota seperti di bandar lampung karena menurut beberapa pesaing yang penulis wawancarai dalam penelitian ini, produk yang sedang trend dan diminati 
oleh konsumen di bandar lampung sama halnya diminati pula oleh konsumen yang berada dipringsewu, namun masyarakat pringsewu seringkali kesulitan dalam menemukan pakaian yang sedang trend tersebut karena butik di pringsewu masih terbilang minim yaitu sekitar 10 butik. Jadi berdasarkan penelitian tersebut penulis menemukan peluang untuk membuka bisnis butik didaerah kabupaten pringsewu.

Berdasarkan peluang-peluang diatas menjadi sebuah dasar untuk mendirikan usaha butik yang akan diberi nama "Lady Center ".

Rencana usaha Butik Lady Center akan memproduksi berbagai jenis pakaian khusunya Gamis, Tunik, Atasan, Celana, Rok, Kemeja dan Kaos,Jaket, Daster, Sweter dan direncanakan berlokasi di Jalan Jendral Ahmad Yani No.189, Sidoharjo

\begin{tabular}{|c|c|}
\hline \multicolumn{2}{|l|}{ Tabel 1.1 Daftar Cost Investasi } \\
\hline Ketetangan & $\begin{array}{l}\text { Total } \\
\text { (RP) }\end{array}$ \\
\hline $\begin{array}{l}\text { Bangunan: } \\
\text { Sewa } 1 \text { Unit Bangunan Ruko 8x12m (10 Thn) } \\
15.000 .000 \\
\text { Renovasi \& Dekorasi Bangunan }\end{array}$ & $\begin{array}{r}150.000 .000 \\
4.000 .000\end{array}$ \\
\hline Total & $154,000,000$. \\
\hline $\begin{array}{l}\text { Peralatan Produksi : } \\
\text { unit Mesin Barcode@2.000.000 } \\
\text { l unit Mesin Kasir@2.000.000 }\end{array}$ & $\begin{array}{l}2.000 .000 \\
2.000 .000\end{array}$ \\
\hline Total & 4.000 .000$. \\
\hline 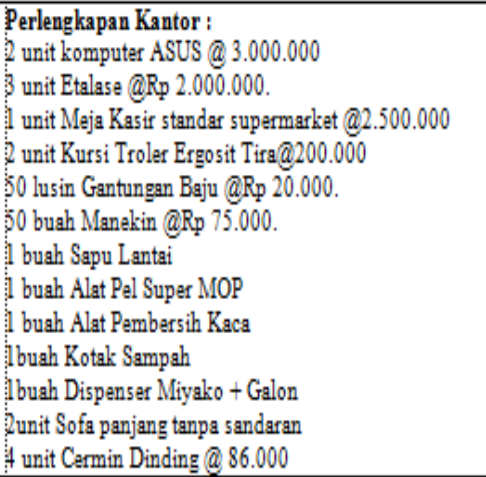 & $\begin{array}{r}6.000 .000 . \\
6.000 .000 . \\
5.000 .000 . \\
400.000 . \\
1.000 .000 . \\
3.750 .000 \text {. } \\
12.000 . \\
95.000 . \\
13.000 . \\
25.000 . \\
500.000 . \\
400.000 . \\
344.000\end{array}$ \\
\hline \begin{tabular}{|ll} 
Total \\
\end{tabular} & $23,539,000$. \\
\hline $\begin{array}{l}\text { Fasilitas: } \\
1 \text { unit AC Samsung AR05KRFLAWK @Rp 2.500.000. } \\
1 \text { unit GensetHonda } \\
2 \text { unitCCTV Portable@Rp } 335.000 \\
\text { 6 unitLampu LED Bulb 5 watt @ Rp } 210.000\end{array}$ & $\begin{array}{r}2.500 .000 \\
2.000 .000 \\
670.000 \\
1.260 .000\end{array}$ \\
\hline Total & 6.430 .000$. \\
\hline Pembuatan Papan/Plang Nama Neon Box (3xlm) & 3.000 .000 \\
\hline Total & 3.000 .000 , \\
\hline Jumlah & 189.969 .000$. \\
\hline
\end{tabular}

Pringsewu Utara Kabupaten Pringsewu, lokasi tersebut dipilih karena belum banyak pesaing pada bisnis butik yang berada di daerah tersebut.

Sebelum mendirikan suatu usaha perlu dilakukan analisis-analisis yang yang dapat menentukan layak atau tidak layak usaha tersebut didirikan antara lain adalah analisis finansial dan analisis nonfinansial.

Untuk mendirikan usaha ini dibutuhkan Biaya (cost) yang tidak sedikit. Cost yang dibutuhkan digunakan untuk membiayai kegiatan investasi dan operasional. Rencana cost yang digunakan untuk investasi dapat dilihat pada Tabel 1.1 dan cost operasional tahun pertama dapat dilihat pada Tabel 1.3. Direncanakan umur rancangan rencana usaha ini selama 10 (sepuluh) tahun.

\begin{tabular}{|c|c|c|c|c|}
\hline Keterangun Biays & Unit & $\begin{array}{l}\text { Bisys } \\
\text { Satuan } \\
\text { (RP) }\end{array}$ & $\begin{array}{l}\text { Biays Bulan } \\
\text { (KP) }\end{array}$ & $\begin{array}{l}\text { Biays Tabur } \\
\text { (RP) }\end{array}$ \\
\hline \multicolumn{5}{|l|}{ 2. Cost Oprasional } \\
\hline \multicolumn{5}{|l|}{ A. Produk } \\
\hline Gamis & $15 \mathrm{ps}$ & 125.000 & 1.875 .000 & 22500000 \\
\hline Aase & $30 \mathrm{pes}$ & 40,000 & 12000000 & 14.400000 \\
\hline Celasa jass & $10 \mathrm{pss}$ & 30.000 & 500,000 & 60000000 \\
\hline Celas Hopeest & $6 \mathrm{pss}$ & 30.000 & 190.000 & 21600000 \\
\hline Colas Dasz & $8 \mathrm{pss}$ & 35.000 & 2500000 & 3360.000 \\
\hline Celase Kadpt & $10 \mathrm{pss}$ & 40.000 & 400,000 & 4.9000000 \\
\hline Kempja & $12 \mathrm{pss}$ & 30.000 & 360,000 & 4320.000 \\
\hline Zaos & $24 \mathrm{pss}$ & 15.000 & 3600000 & 4320.000 \\
\hline Rok Span Dasar & $8 \mathrm{pss}$ & 35.000 & 250,000 & 33600000 \\
\hline Rok Dowerg & $10 \mathrm{pes}$ & 40.000 & 400.000 & 4.900 .000 \\
\hline Rok Rast Stirt & $10 \mathrm{pss}$ & 250000 & 250,000 & 3.000 .000 \\
\hline Rok Tos Sint & $10 \mathrm{pes}$ & 35000 & 380,000 & 42000000 \\
\hline $\operatorname{Tex}$ & $20 \mathrm{pss}$ & 40,000 & 8000000 & 9.600 .000 \\
\hline Jake: & $10 \mathrm{pes}$ & 30.000 & 300,000 & 6000000 \\
\hline Dusser & $15 \mathrm{pss}$ & 35000 & 323,000 & 6300000 \\
\hline $\begin{array}{l}\text { Sress } \\
\text { B. Tenanga Kerja } \\
\text { Langung }\end{array}$ & $12 \mathrm{pss}$ & 30.000 & 360.000 & 4320000 \\
\hline Masajer & $1 \mathrm{cmag}$ & 20000000 & 20000000 & 24.0000 .000 \\
\hline Rasir & 1 crang & 15000000 & 1500,000 & 180000000 \\
\hline $\begin{array}{l}\text { Rarraman } \\
2 \text { Cost Adm Das } \\
\text { Umm }\end{array}$ & 1 corang & 12000000 & 12000000 & 144000000 \\
\hline A Cost Telpoe & & & 300,000 & 6000000 \\
\hline B. Cost Listz & & & 300,000 & 3.600 .000 \\
\hline $\begin{array}{l}\text { Cont Perhaglapua } \\
\text { Zaetse }\end{array}$ & & & 3000000 & 3.6000000 \\
\hline \multirow{2}{*}{ 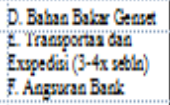 } & & & 50.000 & 600000 \\
\hline & & $\begin{array}{l}2500.000 \\
39000000\end{array}$ & $\begin{array}{l}2500.000 \\
3.8000000\end{array}$ & $\begin{array}{l}30.0000 .000 \\
45.600 .000\end{array}$ \\
\hline \multicolumn{5}{|l|}{ 3. Cost Kebersihan } \\
\hline A Peagharea Rungy & $2 \mathrm{pss}$ & & 50000 & 6000000 \\
\hline $\begin{array}{l}\text { 8. Caras pembersh } \\
\text { anai }\end{array}$ & 1 vait & & 20.000 & 490.000 \\
\hline Julah & & & 20840.000 & $250,320.000$ \\
\hline
\end{tabular}


Berdasarkan data pada Tabel 1.3 cost operasional yang harus dikeluarkan Butik Busana Lady Center pada tahun pertama sebesar Rp 250.320.000,00

Dari data pada Tabel 1.1 dan Tabel 1.3 maka diperhitungkan total cost yang harus dikeluarkan Butik Lady Center dengan cara sebagai berikut :

Total biaya $=$ Cost Investasi + Cost Oprasional

\begin{tabular}{|c|c|c|c|c|}
\hline \multicolumn{5}{|c|}{ Tabel 1.4 Rancangan Benefit Pada Tahun Pertama } \\
\hline Jenis Produk & $\begin{array}{l}\text { Harga } \\
(\mathbb{R P})\end{array}$ & $\begin{array}{c}\text { Rata- } \\
\text { Rata } \\
\text { Penjualan }\end{array}$ & $\begin{array}{c}\text { Jumlah } \\
\text { Perbulan } \\
\text { (RP) }\end{array}$ & $\begin{array}{c}\text { Jumlah Pertalun } \\
\text { (RP) }\end{array}$ \\
\hline Gramis & 300.000 & 8 & 2.400 .000 & 28.806 .000 \\
\hline Gramis Brikst & 350.000 & 3 & 1.050 .000 & 12.606 .000 \\
\hline Atasen & 95.000 & 25 & 2.375 .000 & 28.506 .000 \\
\hline țaso & 50.000 & 20 & 1.000 .000 & 12.006 .000 \\
\hline Turik & 120.000 & 16 & 1.920 .000 & 23.040 .000 \\
\hline Semgja & 85.000 & 10 & 850.000 & 10.200 .000 \\
\hline Crdigan & 85.000 & 8 & 680.000 & 8.166 .000 \\
\hline Salket & 150.000 & 7 & 1.050 .000 & 12.606 .000 \\
\hline Soomber & 120.000 & 8 & 960.000 & 11.526 .000 \\
\hline Doster & 125.000 & 10 & 1.250 .000 & 15.006 .000 \\
\hline S़िter & 85.000 & 9 & 765.000 & 9.186 .000 \\
\hline Celana Jeans & 170.000 & 7 & 1.190 .000 & 14.286 .000 \\
\hline Celana denim & 150.000 & 7 & 1.050 .000 & 12.600 .000 \\
\hline Celana Joger & 120.000 & 7 & 840.000 & 10.086 .000 \\
\hline Celsns Hotpents & 75.000 & 4 & 300.000 & 3.606 .000 \\
\hline Celang Dasar & 85.000 & 5 & 425.000 & 5.100 .000 \\
\hline Celana training & 75.000 & 5 & 375.000 & 4.506 .000 \\
\hline Celana Kulot & 110.000 & 8 & 880.000 & 10.566 .000 \\
\hline Rol Span Dasar & 85.000 & 5 & 425.000 & 5.106 .000 \\
\hline Rok Duyung & 100.000 & 7 & 700.000 & 8.400 .000 \\
\hline tol. Flare jesns & 120.000 & 10 & 1.200 .000 & 14.400 .000 \\
\hline Rok Flare Skint & 85.000 & 6 & 510.000 & 6.126 .000 \\
\hline Rok Tutu Skrilt & 100.000 & 8 & 800.000 & 9.600 .000 \\
\hline Rol Long Skrsit & 98.000 & 10 & 980.000 & 11.766 .000 \\
\hline TOTAL & & 232 & 23.975 .000 & 287.700 .000 \\
\hline
\end{tabular}

Perkiraan benefit pada tahun pertama Butik Lady Center akan mendapat benefit sebesar Rp 287.700.000, Butik Lady Center direncanakan priode perputaran perdana
$=\operatorname{Rp} 189.969 .000+\operatorname{Rp} 20.840 .000$

$=\operatorname{Rp} 210.809 .000$

Butik Lady Center membutuhkan modal sebesar Rp 211.000.000 yang sebagian diperoleh dengan kredit di Bank BNI dengan rincian : Modal Sendiri : $\mathrm{Rp}$ 111.000.000 dan Pinjam Bank : Rp 100.000 .000 dengan bunga $10 \%$ pertahun dalam jangka waktu 3 tahun.

pada butik ini akan dilakukan selama satu bulan sekali untuk tahun pertama.

Dari data-data tersebut perusahaan memerlukan analisis kelayakan bisnis untuk mengetahui gambaran tentang kelayakan usaha Butik Lady Center. Berdasarkan masalah tersebut dapat dirumuskan permasalahan: 1) Apakah rencana usaha Butik Lady Center di Pringsewu layak atau tidak layak dilaksanakan berdasarkan analisis finansial kriteria investasi ? 2) Berapa lama jangka waktu pengembalian investasi (Pay Back Period) rencana usaha Butik Lady Center di Pringsewu ? 3) Berapa lama jangka waktu break even (Break Even Point Period) rencana usaha Butik Lady Center di Pringsewu ? 4) Apakah rencana usaha Butik Lady Center di Pringsewu layak atau tidak layak dilaksanakan berdasarkan analisis non finansial ?

Tujuan penelitian ini yaitu : 1) Untuk mengetahui layak atau tidaknya rencana pendirian usaha Butik Lady Center di Pringsewu berdasarkan analisis finansial kriteria investasi 2) Untuk mengetahui jangka waktu pengembalian investasi (Pay Back Period) rencana pendirian usaha Butik Lady Center di Pringsewu. 3) Untuk mengetahui jangka waktu terjadinya titik pulang pokok (Break Even Point Period) dari rencana pendirian usaha Butik Lady Center di Pringsewu. 4) Untuk mengetahui layak atau tidaknya rencana pendirian usaha Butik Lady Center di Pringsewu berdasarkan analisis non finansial. 


\section{Tinjauan Pustaka, Kerangka Konseptual.}

Bisnis . menurut M.Ma'ruf Abdullah (2017 : 1) "Bisnis adalah salah satu bentuk ekonomi yang sangat dinamis, dan dinamikanya itu sangat ditentukan oleh sumber daya organisasi yang ada dalam bisnis itu, yaitu: man (orang), money (dana), material (peralatan), mechine (mesin), dan method (cara menggerakkannya)". Kasmir \& Jakfar (2012 : 7) menyatakan "Studi kelayakan bisnis adalah suatu kegiatan yang mempelajari secara mendalam tentang suatu usaha atau bisnis yang akan dijalankan, dalam rangka menentukan layak atau tidak usaha tersebut". Untuk mengetahui kelayakan suatu rencana usaha diperlukan analisis finanasial dan non finansial.

Analisis finansial adalah analisis yang digunakan untuk menentukan kelayakan suatu rencana usaha dari sisi finansial dengan menggunakan alat ukur kriteria investasi, Analisis Kreteria Investasi. Menurut Yacob Ibrahim (2009: 141) "Tujuan dari perhitungan kriteria investasi adalah untuk mengetahui sejauh mana gagasan usaha (proyek) yang direncanakan dapat memberikan manfaat (benefit), baik dilihat dari finansial benefit maupun sosial benefit". Selanjutnya dinyatakan juga oleh Sapmaya Wulan dalam buku bahan ajar analisis kelayakan bisnis prodi manajemen universitas bandar lampung (2015 : 35) Kriteria Investasi terdiri dari : a. Net Present Value (NPV) NPV adalah selisih selisih benefit dengan cost pada tingkat bunga (Discount Rate) tertentu. Selisih benefit dengan cost adalah selisih yang dinilai sekarang. Kriteria NPV > 0, maka proyek dinyatakan layak untuk dilaksanakan dan jika NPV $<0$, maka proyek dinyatakan tidak layak dilaksanakan. b. Net Benefit Cost Ratio $(\mathrm{Net} B / \mathrm{C})$ Net B/C adalah perbandingan antara jumlah NPV positif dengan NPV negatif. Kriteria Net B/C adalah jika Net $\mathrm{B} / \mathrm{C}>1$, maka rencana proyek dinyatakan layak untuk dilaksanakan dan jika Net B/C $<$ 1, maka proyek tidak layak untuk dilaksanakan. c. Gross Benefit Cost Ratio (Gross B/C) Gross B/C adalah perbandingan antara jumlah present value benefit dengan present value cost. Kriteria Gross B/C adalah jila Gross B/C > 1, maka proyek dinyatakan layak untuk dilaksanakan dan jika Gross B/C < 1, maka proyek dinyatakan tidak layak untuk dilaksanakan. d. Internal Rate Of Return (IRR) IRR adalah persentase keuntungan yang diperoleh dari suatu proyek pada tiap-tiap tahun. IRR juga merupakan alat ukur kemampuan proyek dalam mengembalikan bunga pinjaman. Kriteria IRR adalah jika IRR > tingkat bunga yang berlaku, maka dinyatakan layak untuk dilaksanakan, dan jika IRR < tingkat bunga berlaku, maka rencana proyek tidak layak untuk dilaksanakan. e. Probability Ratio (PR) PR adalah perbandingan antara jumlah present value net benefit dengan jumlah present value investasi. Kriteria PR adalah jika PR > 1, maka rencana proyek dinyatakan layak untuk dilaksanakan, dan jika $\mathrm{PR}<1$, maka rencana proyek dinyatakan tidak layak untuk dilaksanakan. Analisis Pay Back Period. Pay Back Period adalah suatu analisis yang digunakan untuk melihat jangka waktu kembalinya investasi yang telah dikeluarkan melalui keuntungan yang diperoleh dari suatu proyek. Ada 2 (dua) metode untuk menghitung pay back period yaitu Metode Net Benefit Kumulatif dan Metode Net Benefit rata-rata tiap tahun.

Analisis Break Even Point (BEP). Break Even Point (BEP) juga diperlukan dalam studi kelayakan bisnis. Analisis Break Even Point (BEP) adalah titik pulang pokok dimana total revenue (penerimaan) = total cost (total pengeluaran) atau suatu keadaan dimana perusahaan telah mendapatkan keuntungan dan tidak mengalami kerugian. Tujuan dari analisis ini adalah untuk menghitung atau mengetahui kapan BEP terjadi atau jangka waktu terjadi BEP. 
Aspek-aspek Studi Kelayakan Bisnis. Aspek non finansial terdiri dari beberapa aspek yang tidak dapat berdiri sendiri dan saling berhubungan satu dengan yang lain. Analisis non finansial dilakukan dengan menganalisis beberapa aspek yaitu : a) Aspek teknis adalah hal-hal yang berhubungan dengan kebutuhan teknis proyek baik dalam bentuk barang maupun jasa (fisik maupun non fisik) yang dibutuhkan proyek yang meliputi faktor lokasi,bangunan,fasilitas/mesin/perlengkap an/-peralatan, kapasitas, dan luas produksi. (Kasmir \& Jakfar, 2012 : 27). b) Aspek pasar dan pemasaran adalah aspek yang mengkaji hal-hal yang berkaitan dengan pasar dan pemasaran untuk barang dan jasa yang dihasilkandari kegiatan usaha/proyek. (Kasmir \& Jakfar, 2012 : 26). c) Aspek birokrasi adalah segala sesuatu yang berhubungandenganpersyaratan

administrasi proyek yang berkaitan denganadministrasipemerintahan.

(Sapmaya Wulan dalam buku ajar analisis kelayakan bisnis prodi manajemen universitas bandar lampung 2015 : 23). d) Aspek Hukum adalah segala sesuatu yang berhubungan dengan peraturan perundangundangan, peraturan pemerintah baik pusat maupun daerah dan peraturan-peraturan lain yang berkaitan dengan pendirian/pelaksanaan-/pengolahan usaha/proyek. (Kasmir \& Jakfar, 2012 : 23). e) Aspek manajemen dan MSDM adalah aspek yang bertujuan untuk mengetahui apakah pembangunan dan implementasi bisnis dapat direncanakan, dilaksanakan, dan dikendalikan, sehingga rencana bisnis dapat dinyatakan layak, atau sebaliknya. (Husein Umar, 2009 :114). f) Aspek ekonomis adalah aspek yang mengkaji tentang peranan/sumbangan/manfaat perusahaan dalam pengembangan perekonomian secara keseluruhan/makro. (Kasmir \& Jakfar, 2012 : 27). g) Aspek lingkungan adalah aspek yang bertujuan untuk menentukan apakah secara lingkungan hidup misalnya dari sisi udara dan air rencana bisnis diperkirakan dapat dilaksanakan secara layak atau sebaiknya. (Husein Umar, 2009 : 302). Dari uraian diatas dapat digambarkan paradigma penelitian pada Gambar 1.

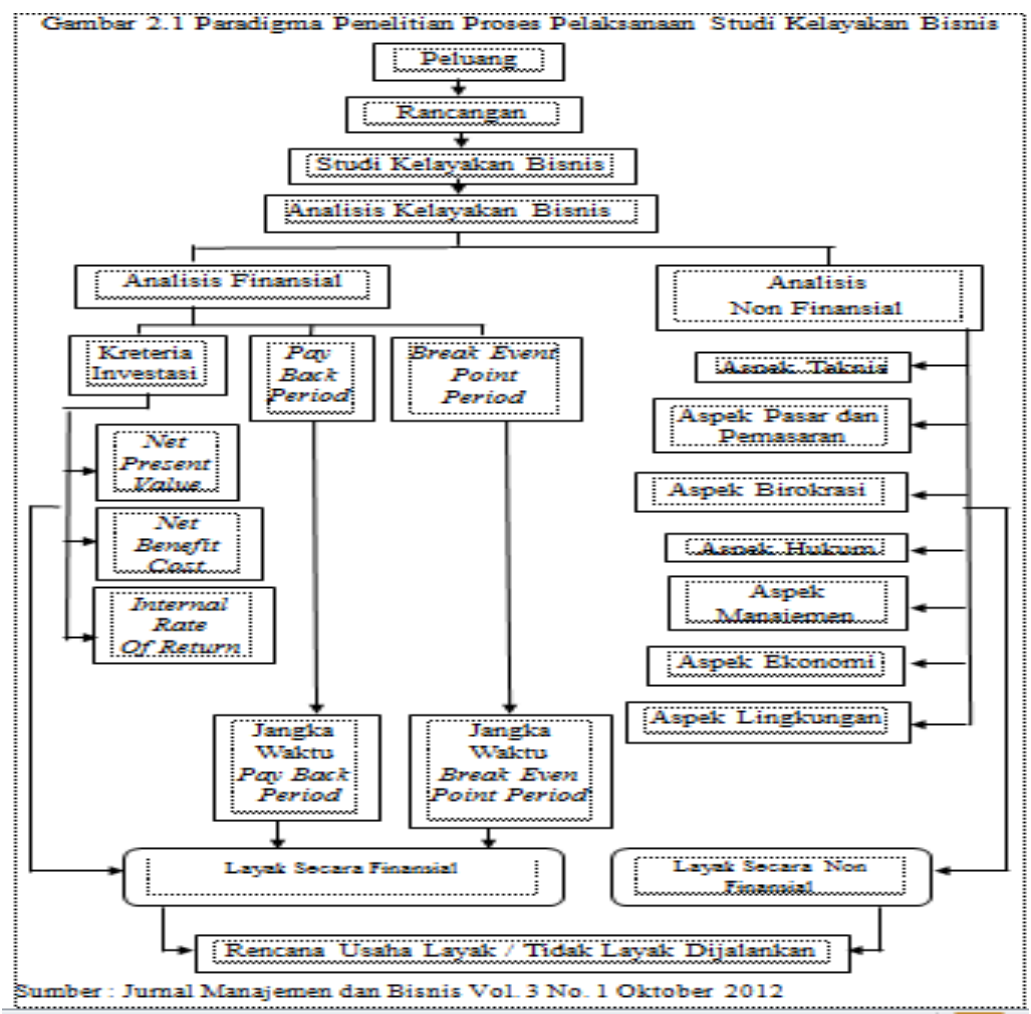




\section{METODE PENELITIAN}

\section{Jenis Penelitian}

1. Penelitian Kepustakaan (Library Research) Yaitu dengan mempelajari berbagai laporan-laporan karangan ilmiah serta literatur dan sejenisnya yang berhubungan dengan permasalahan yang sedang diteliti.

2. Penelitian Lapangan (Field Reseach) Yaitu suatu cara untuk memperoleh data yang berhubungan dengan obyek penelitian yang dilakukan dengan pengamatan pada obyek penelitian.

Sumber Data. Data yang digunakan dalam penyusunan skripsi ini dibagi atas 2 macam, yaitu: Data Primer, adalah data yang diperoleh atau dikumpulkan sendiri secara langsung melalui sumbernya sehingga data yang diperoleh dapat dipercaya. Data Sekunder, adalah data yang diperoleh dari literatur-literatur yang dilakukan melalui media kepustakaan yang berkaitan dengan pem-bahasan skripsi ini.

\section{Metode Analisis}

Metode Analisis Kuantitatif, analisis dilakukan dengan perhitungan menggunakan alat, model atau rumus untuk menjawab permasalahan penelitian. Alat/rumus yang digunakan adalah Kriteria Investasi, Analisis Pay Back Period dan Break Event Point. Kriteria Investasi yang digunakan dalam penelitian ini adalah Net Present Value (NPV), Net Benefit Cost Ratio (Net B/C), dan Internal Rate of Return (IRR).

$$
\begin{aligned}
& \text { Net Present Value (NPV) } \\
& \mathrm{t}=\mathrm{n} \\
& \mathrm{NPV}=\sum\left(\mathrm{B}_{\mathrm{t}}-\mathrm{C}_{\mathrm{t}}\right) \times\left(\frac{1}{(1+i)^{t}}\right) \\
& \mathrm{t}=0 \\
& \mathrm{t}=\mathrm{n} \\
& \text { NPV } \left.=\sum \text { ( Net Benefit }\right) \times \text { DF } \\
& \mathrm{t}=0
\end{aligned}
$$

(Abdul Choliq, 1999; 33)
$\mathrm{Bt}=$ benefit pada tahun $\mathrm{ke}-\mathrm{t}$

$\mathrm{Ct}=$ biaya pada tahun $\mathrm{ke}-\mathrm{t}$

DF $=$ Discount Factor

$\mathrm{i}=$ tingkat bunga yang berlaku

$\mathrm{n}=$ lamanya periode waktu

Kriteria investasi NPV : Jika NPV > 0, maka rencana proyek/usaha layak dilaksanakan. Jika NPV $<0$, maka rencana proyek/ usaha tidak layak dilaksanakan.

\section{Net Benefit Cost Ratio (Net B/C)}

$$
\text { Net } \mathrm{B} / \mathrm{C}=\frac{\sum_{\mathrm{t}=0}^{\mathrm{t}-\mathrm{n}} \mathrm{NPV} \text { Positif }}{\sum_{\mathrm{t}=0}^{\mathrm{t}=\mathrm{n}} \mathrm{NPV} \text { Negatif }}
$$

(Abdul Choliq, dkk, 1999; 35)

Keterangan :

NPV $+=$ Net Present Value positif NPV- = Net Present Value negatif

Kriteria investasi Net B/C: Jika Net B/C > 1, maka proyek/usaha layak dilaksanakan. Jika Net B/C $<1$, maka proyek/usaha tidak layak dilaksanakan.

\section{Internal Rate of Return(IRR)}

$$
\mathrm{IRR}=\mathrm{i}_{1}+\left\{\frac{\text { NPV Positif }}{\text { NPV positif }- \text { NPV negatif }} \times\left(\mathrm{i}_{2}-\mathrm{i}_{1}\right)\right\}
$$

(Abdul Choliq, 1999; 38)

Keterangan :

i1 = tingkat bunga yang menghasilkan NPV positif yang paling mendekati 0 i2 = tingkat bunga yang menghasilkan NPV negatif yang paling mendekati 0 $\mathrm{NPV}+=$ NPV yang menghasilkan i1 NPV- = NPV yang menghasilkan i2

Kriteria IRR : Jika IRR > tingkat bunga yang berlaku maka rencana proyek/usaha layak dilaksanakan. Jika IRR < tingkat bunga yang berlaku maka rencana proyek/ usaha tidak layak dilaksanakan.

Keterangan : 
Analisis Pay Back Period (PBP)

Metode Net Benefit Cumulative dengan rumus :

$\mathrm{PBP}=\mathrm{T}_{\mathrm{P}-1}+\frac{\text { sisa hutang }}{\text { net benefit setelah sisa hutang }} \times 12 \mathrm{bln}$

(Yacob Ibrahim, $2003: 154$ )

Keterangan :

PBP $=$ Pay Back Period

TP-1 = tahun sebelum terdapat PBP

Metode Analisis Kualitatif. Analisis ini dilakukan untuk menganalisis data dengan menggunakan penalaran dengan berpedoman pada pendekatan teoritis.

HASIL PENELITIAN DAN ANALISIS DATA

\section{Metode Analisis Kuantitatif}

Dalam Metode Analisis Kuantitatif yang digunakan adalah analisis finanasial yang terdiri dari 3 alat analisis yaitu :

1. Kriteria Investasi

Kriteria Investasi yang akan digunakan dalam penelitian ini terdiri dari :

Net Present Value (NPV),Net Benefit Cost Ratio (Net B/C) dan Internal Rate Of Return (IRR)

2. Pay Back Pariod (PBP)

3. Break Even Point Period (BEPP).

\section{Kriteria Investasi}

Untuk keperluan perhitungan analisis kriteria investasi diperlukan data cost investasi yang dapat dilihat pada tabel 1.1 cost investasi pada tahun pertama yaitu Rp. 189.969.000. Kemudian untuk merancang biaya operasional perdana biaya yang dikeluarkan sebesar Rp. 250.320.000. cost operasional mengalami kenaikan dari tahun ke tahun. Pada tahun ke-1 (satu) belum ada kenaikan karena baru memulainya usaha tersebut sedangkan pada tahun ke-2 (dua) ke-3 (tiga) dan ke-4 (empat) mengalami kenaikan yang sama yaitu sebesar 5\%, tahun ke-5 (lima) terjadi peningkatan sebesar $10 \%$, pada tahun ke-6 (enam)
Kalaupun ada data berupa angka-angka sifat analisisnya hanya terbatas pada pemberian informasi, menilai, atau mengevaluasi data angka tersebut, kemudian melakukan pendekatan teoritis dengan menganalisis dari aspek-aspek analasis kelayakan bisnis yang meliputi :
a. Aspek Teknis
b. Aspek Pasar dan Pemasaran
c. Aspek Birokrasi
d. Aspek Hukum
e. Aspek Manajemen
f. Aspek Ekonomis
g. Aspek Lingkungan

tahun ke-7 (tujuh) dan tahun ke-8 (delapan) terjadi kenaikan sebesar 15\%, sedangkan tahun ke-9 (sembilan) dan tahun ke-10 (sepuluh) meningkat sebesar $20 \%$ dari tahun. Sebelumnya peneliti telah merancang biaya operasional untuk tahun pertama yang dapat dilihat pada Tabel 1.3

Tabel 4.1 Rancangan Cost Oprasional Butik Lady Center

\begin{tabular}{|c|c|c|}
\hline Tahun & $\begin{array}{c}\text { Jumlah } \\
\text { Ke }\end{array}$ & $\begin{array}{c}\text { Cost Operasional } \\
\text { (RP) }\end{array}$ \\
\hline 1 & & 250.320 .000 \\
\hline 2 & $5 \%$ & 262.836 .000 \\
\hline 3 & $5 \%$ & 275.977 .800 \\
\hline 4 & $5 \%$ & 289.776 .690 \\
\hline 5 & $10 \%$ & 318.754 .359 \\
\hline 6 & $15 \%$ & 366.567 .513 \\
\hline 7 & $15 \%$ & 421.552 .640 \\
\hline 8 & $15 \%$ & 484.785 .536 \\
\hline 9 & $20 \%$ & 581.742 .643 \\
\hline 10 & $20 \%$ & 698.091 .171 \\
\hline Sumber & Datan & \\
\hline
\end{tabular}

Tabel 4.2 Rancangan Cost Rencana Usaha Butik Lady Center

\begin{tabular}{|c|c|c|c|}
\hline $\begin{array}{c}\text { Tahun } \\
\mathrm{Ke}\end{array}$ & Cost Investasi & Cost Operasional & Total Cost \\
\hline & (RP) & (RP) & (RP) \\
\hline 0 & 189.969 .000 & - & 189.969 .000 \\
\hline 1 & & 250.320 .000 & 250.320 .000 \\
\hline 2 & & 262.836 .000 & 262.836 .000 \\
\hline 3 & & 275.977 .800 & 275.977 .800 \\
\hline 4 & & 289.776 .690 & 289.776 .690 \\
\hline 5 & & 318.754 .359 & 318.754 .359 \\
\hline 6 & & 366.567 .513 & 366.567 .513 \\
\hline 7 & & 421.552 .640 & 421.552 .640 \\
\hline 8 & & 484.785 .536 & 484.785 .536 \\
\hline 9 & & 581.742 .643 & 581.742 .643 \\
\hline 10 & & 698.091 .171 & 698.091 .171 \\
\hline
\end{tabular}


Selanjutnya untuk melakukan analisis kriteria investasi diperlukan data benefit Berdasarkan rancangan yang telah dibuat peneliti pada Tabel 1.4 benefit tahun pertama sebesar Rp 287.700.000. untuk tahun selanjutnya akan mengalami peningkatan pada tahun ke-2 (dua) meningkat $5 \%$, sedangkan pada tahun ke-3 (tiga) tahun ke-4 (empat) dan tahun ke-5 (lima) mengalami kenaikan yang sama yaitu $10 \%$, pada tahun ke-6 (enam) mengalami kenaikan dari tahun sebelumnya sebesar $15 \%$ sedangkan tahun ke-7 (tujuh) dan tahun ke-8 (delapan) terjadi peningkatan sebesar $20 \%$, selanjutnya pada tahun ke-9 (sembilan) dan tahun ke-10 (sepuluh) mengalami kenaikan yang serupa yaitu meningkat 25\% dari tahun sebelumnya. Untuk lebih memperjelas rancangan benefit dapat dilihat pada Tabel 4.3 sebagai berikut :

\section{Tabel 4.3 Rancangan Benefit Rencana Usaha Butik Lady Center}

\begin{tabular}{|c|c|c|}
\hline Tahun & Jumlah Peningkatan & $\begin{array}{c}\text { Jumlah Benefit } \\
(\mathbb{R P})\end{array}$ \\
\hline Ke & $(\%)$ & 287.700 .000 \\
\hline 1 & $\cdot$ & 302.055 .000 \\
\hline 2 & $5 \%$ & 332.293 .500 \\
\hline 3 & $10 \%$ & 365.522 .850 \\
\hline 4 & $10 \%$ & 402.075 .135 \\
\hline 5 & $10 \%$ & 462.386 .405 \\
\hline 6 & $15 \%$ & 554.863 .686 \\
\hline 7 & $20 \%$ & 665.836 .424 \\
\hline 8 & $20 \%$ & 832.295 .529 \\
\hline 9 & $25 \%$ & 1.040 .360 .412 \\
\hline 10 & $25 \%$ & \\
\hline
\end{tabular}

Sumber: Data Diolah (2018)

Berdasarkan data total cost Tabel 4.2 dan data benefit Tabel 4.3 selanjutnya dibuatlah tabel benefit (cash in flow) dan cost (cash out flow). Untuk keperluan analisis maka dapat digabungkan Tabel 4.2 dan Tabel 4.3 dapat dilihat sebagai berikut
Tabel 4.4 Rancangan Cash in Flow dan Cash out Flow Usaha Butik Lady Center

\begin{tabular}{c|c|c|}
\hline $\begin{array}{c}\text { Tahun } \\
\text { Ke }\end{array}$ & $\begin{array}{c}\text { Cash in Flow } \\
\text { Benefit }\end{array}$ & Cash out Flow \\
\cline { 2 - 3 } & Cost \\
\hline 0 & - & (RP) \\
\hline 1 & 287.700 .000 & 189.969 .000 \\
\hline 2 & 302.085 .000 & 250.320 .000 \\
\hline 3 & 332.293 .500 & 262.836 .000 \\
\hline 4 & 365.522 .850 & 275.977 .800 \\
\hline 5 & 402.075 .135 & 289.776 .690 \\
\hline 6 & 462.386 .405 & 318.754 .359 \\
\hline 7 & 554.863 .686 & 366.567 .513 \\
\hline 8 & 665.836 .424 & 421.552 .640 \\
\hline 9 & 832.295 .529 & 484.785 .536 \\
\hline 10 & 1.040 .369 .412 & 581.742 .643 \\
\hline$\sum$ & 5.245 .427 .941 & 698.091 .171 \\
\hline \multicolumn{2}{|c|}{} \\
\hline
\end{tabular}

Sumber : Data Diolah (2018)

Berdasarkan rancangan cash in flow dan cash out flow pada Tabel 4.4 dapat diketahui perbandingan hasil dari jumlah benefit sebesar Rp. 5.245.427.941 dan jumlah cost sebesar Rp. 4.140.373.352

Maka berdasarkan Tabel 4.2, 4.3, dan 4.4 selanjutnya dapat dilakukan perhitungan analisis kriteria investasi yang terdiri dari Net Present Value (NPV), Net Benefit Cost Ratio (Net B/C), dan Internal Rate Of Return (IRR). Selain menghitung kriteria investasi dilakukan pula perhitungan Pay Back Period (PBP) dan Break Even Point Period(BEPP). 
4.5 Tabel Kriteria Investasi

\begin{tabular}{|c|c|c|c|c|c|c|c|c|c|c|}
\hline $\begin{array}{c}\text { Tahun } \\
\text { Ke }\end{array}$ & $\begin{array}{c}\text { Benefit } \\
\text { (RP) }\end{array}$ & $\begin{array}{l}\text { Cost } \\
\text { (RP) }\end{array}$ & $\begin{array}{c}\text { Net Benefit } \\
\text { (RP) }\end{array}$ & $\begin{array}{c}\text { DF } \\
10 \%\end{array}$ & $\begin{array}{l}\text { NPV } \\
(\mathrm{RP})\end{array}$ & & $\begin{array}{c}\text { DF } \\
35 \%\end{array}$ & $\begin{array}{l}\text { NPV } \\
\text { (RP) }\end{array}$ & $\begin{array}{c}\text { DF } \\
36 \%\end{array}$ & $\begin{array}{l}\text { NPV } \\
\text { (RP) }\end{array}$ \\
\hline (1) & (2) & (3) & (4) $(2-3)$ & (5) & $(6)=(4 \times 5)$ & & (5) & $(6)=(4 \times 5)$ & (5) & $(6)=(4 \times 5)$ \\
\hline 0 & - & 189.969 .000 & (189.969.000) & 1,000 & $(189.969 .000)$ & $\begin{array}{c}\text { NPV } \\
\text { Negatif }\end{array}$ & 1,000 & (189.969.000) & 1,000 & $(189.969 .000)$ \\
\hline 1 & 287.700 .000 & 250.320 .000 & 37.380 .000 & 0,909 & 33.981 .818 & 189.969 .000 & 0,741 & 27.688 .889 & 0,735 & 27.485 .294 \\
\hline 2 & 302.085 .000 & 262.836 .000 & 39.249 .000 & 0,826 & 32.437 .190 & & 0,549 & 21.535 .802 & 0,541 & 21.220 .264 \\
\hline 3 & 332.293 .500 & 275.977 .800 & 56.315 .700 & 0,751 & 42.310 .819 & & 0,406 & 22.889 .072 & 0,398 & 22.387 .869 \\
\hline 4 & 365.522 .850 & 289.776 .690 & 75.746 .160 & 0,683 & 51.735 .646 & & 0,301 & 22.804 .762 & 0,292 & 22.141 .395 \\
\hline 5 & 402.075 .135 & 318.754 .359 & 83.320 .776 & 0,621 & 51.735 .646 & & 0,223 & 18.581 .658 & 0,215 & 17.908 .482 \\
\hline 6 & 462.386 .405 & 366.567 .513 & 95.818 .892 & 0,564 & 54.087 .267 & NPV Positif & 0,165 & 15.828 .820 & 0,158 & 15.143 .201 \\
\hline 7 & 554.863 .686 & 421.552 .640 & 133.311 .046 & 0,513 & 68.409 .646 & 277.443 .569 & 0,122 & 16.312 .847 & 0,116 & 15.491 .511 \\
\hline 8 & 665.836 .424 & 484.785 .536 & 181.050 .888 & 0,467 & 84.461 .575 & & 0,091 & 16.410 .829 & 0,085 & 15.469 .967 \\
\hline 9 & 832.295 .529 & 581.742 .643 & 250.552 .886 & 0,424 & 106.258 .882 & & 0,067 & 16.822 .692 & 0,063 & 15.741 .613 \\
\hline 10 & 1.040 .369 .412 & 698.091 .171 & 342.278 .241 & 0,386 & 131.963 .079 & & 0,050 & 17.023 .216 & 0,046 & 15.812 .124 \\
\hline$\sum$ & 5.245 .427 .941 & 4.140 .373 .352 & 1.105 .054 .589 & & 467.412 .569 & & & 5.929 .586 & & $(1.167 .280)$ \\
\hline
\end{tabular}




\section{a. Net Present Value (NPV)}

Berikut ini rancangan Net Present Value (NPV) yang akan disajikan pada tabel 4.5kolom6 Berdasarkan perhitungan dengan menggunakan rumus Net Present Value (NPV) selama 10 tahun dapat diperoleh hasil sebesar Rp 467.412.569. Tabel rancangan Net Present Value (NPV) Tabel 4.5 menunjukan NPV > 0 maka rencana pendirian usaha Butik Lady Center dinyatakan layak untuk dilaksanakan/go.

\section{b.Net Benefit Cost Ratio (Net B/C)}

Selanjutnya rancangan Net Benefit Cost Ratio (Net B/C) dapat disajikan dalam Tabel 4.5 kolom 7 . Berdasarkan Tabel rancangan Net Benefit Cost Ratio (Net B/C) Tabel 4.6, diperoleh jumlah Net Present Value(NPV) Positif sebesar Rp. 277.443.569 dan Net Present Value (NPV) Negatif sebesar Rp. 189.969.000 . Berarti perhitungan Net Benefit Cost Ratio (Net B/C) adalah :

$$
1,19
$$

Net $\mathrm{B} / \mathrm{C}=$

Berdasarkan perhitungan diatas, diperoleh Net Benefit Cost Ratio (Net B/C) sebesar 1,19 hal ini menunjukkan bahwa Net B/C $>1$. berarti rencana pendirian usaha Butik Lady Center ini layak untuk dijalankan (go).

\section{c.Internal Rate of Return (IRR)}

Dalam mencari Internal Rate of Return (IRR) ada beberapa prosedur atau langkahlangkah yang harus dilakukan yaitu sebagai berikut :

Menyiapkan data Benefit dan Cost Tabel 4.3

1) Menghitung Net Present Value pada tingkat bunga yang berlaku yaitu 10\%, diperoleh Net Present Value sebesar $\mathrm{Rp}$ 467.412.569. Untuk mencari Internal Rate of Return dibutuhkan Net present Value $=0$ atau Net present Value yang mendekati $0, \quad$ maka dilanjutkan langkah berikutnya.

2) Menghitung Net Present Value pada berbagai Tingkat Bunga (i) dengan melakukan uji coba sampai mendapatkan Net Present Value Positif yang mendekati 0 dan Net present ValueNegatif yang mendekati 0 . Uji coba yang dilakukan yaitu menggunakan Tingkat Bunga (i) $=32 \%, 37 \%$, $35 \%$, dan $36 \%$. Perhitungan uji coba dalam mencari Net Present Value yang mendekati 0 dapat dilihat pada lampiran 2 Perhitungan Internal Rate of Return (uji coba untuk mencari Net Present Value yang mendekati 0).

3) Setelah dilakukan beberapa perhitungan uji coba diperoleh $\mathrm{Net}$ Present Value Positif yang mendekati $0=\operatorname{Rp} 5.929 .586$ pada $\mathrm{i}_{1}=35 \%$ dan Net Present Value Negatif yang mendekati $0=-\mathrm{Rp}$ 1.167.280 pada $\mathrm{i}_{2}=36 \%$. Jadi besarnya Internal Rate Of Return adalah antara $35 \%$ dan $36 \%$. Berikut ini Tabel rancangan Internal Rate Of Return (IRR) yang disajikan pada Tabel 4.5 kolom 8 sampai dengan kolom 11.

4) Menghitung Internal Rate $O f$ Return dengan rumus Interpolasi antara $\mathrm{i}_{1}=35 \%$ yang menghasilkan Net Present Value Positif sebesar Rp 5.929.586 yang mendekati 0 dan $\mathrm{i}_{2}=36 \%$ yang menghasilkan Net Present Value Negatif sebesar - Rp 1.167.280 yang mendekati 0 .

5) Selanjutnya untuk mementukan kepastian akurasi IRR maka digunakan Rumus Interpolasi : 
6) Dengan demikian Internal Rate Of Return (IRR) yang diperoleh Butik Lady Center pada setiap tahunnya adalah sebesar $35,83 \%$.

Berdasarkan perhitungan diatas, berarti nilai Internal Rate of Return (IRR) lebih besar (>) dari Tingkat Bunga yang berlaku yaitu $10 \%$, maka rencana pendirian usaha Butik Lady Center ini layak untuk dijalankan $(\mathrm{go})$.
Analisis Pay Back Period (PBP) Pay Back Period (PBP) bertujuan untuk mengetahui kapan jangka waktu kembalinya investasi yang telah dikeluarkan melalui keuntungan yang diperoleh dari usaha yang akan dijalankan. Untuk itu berdasarkan rencana benefit dan rencana cost pada Tabel 4.4 diatas, maka dibuat Tabel 4.8 yaitu Perhitungan PBP

\subsection{Tabel Perhitungan Pay Back Period Rencana Usaha Butik Busana Lady Center}

\begin{tabular}{|c|c|c|c|c|c|}
\hline Tahun Ke & $\begin{array}{c}\text { Benefit } \\
\text { (RP) }\end{array}$ & $\begin{array}{l}\text { Cost } \\
\text { (RP) }\end{array}$ & $\begin{array}{c}\text { Net Benefit } \\
\text { (RP) }\end{array}$ & $\begin{array}{c}\text { Net } \\
\text { Benefit } \\
\text { Kumulatif }\end{array}$ & \\
\hline (1) & (2) & (3) & (4) $(2-3)$ & (RP) & \\
\hline 0 & - & 189.969 .000 & (189.969.000) & $(189.969 .000)$ & \\
\hline 1 & 287.700 .000 & 250.320 .000 & 37.380 .000 & (152.589.000) & \\
\hline 2 & 302.085 .000 & 262.836 .000 & 39.249 .000 & $(113.340 .000)$ & \\
\hline 3ТP-1 & 332.293 .500 & 275.977 .800 & 56.315 .700 & $(57.024 .300)$ & $\begin{array}{l}\text { Sisa } \\
\text { Hutang }\end{array}$ \\
\hline $4 \mathrm{TP}$ & 365.522 .850 & 289.776 .690 & 75.746 .160 & 18.721 .860 & PBP \\
\hline 5 & 402.075 .135 & 318.754 .359 & 83.320 .776 & 102.042 .636 & \\
\hline 6 & 462.386 .405 & 366.567 .513 & 95.818 .892 & 197.861 .528 & \\
\hline 7 & 554.863 .686 & 421.552 .640 & 133.311 .046 & 331.172 .574 & \\
\hline 8 & 665.836 .424 & 484.785 .536 & 181.050 .888 & 512.223 .462 & \\
\hline 9 & 832.295 .529 & 581.742 .643 & 250.552 .886 & 762.776 .348 & \\
\hline 10 & 1.040 .369 .412 & 698.091 .171 & 342.278 .241 & 1.105.054.589 & \\
\hline$\Sigma$ & 5.245.427.941 & 4.140.373.352 & 1.105.054.589 & 2.516.930.697 & \\
\hline
\end{tabular}

Sumber: Data Diolah 2018

Berdasarkan Tabel perhitungan Pay Back Period diatas dapat diketahui bahwa pada tahun ke 0 (nol) net benefit masih negative karena perusahaan baru melakukan investasi. Net benefit kumulatif pada tahun ke-1, tahun ke-2, dan tahun ke-3 masih negatif sehingga masih belum terjadi Pay Back Period dan pada tahun ke-4 Net benefit kumulatif telah memiliki nilai yang positif yang berarti telah terjadi Pay Back Period. Pada tabel 4.8 selain menghitung net benefit dihitung juga Net Benefit Kumulatif yang bertujuan untuk mengetahui kapan terjadinya pay back period (PBP) atau kapan kembalinya investasi.

Berikut ini adalah cara perhitungan dengan menggunakan rumus Metode Net Benefit kumulatif diatas guna untuk mencari waktu kembalinya investasi Butik Busana Lady Center yaitu : 
$\mathrm{PBP}=3$ tahun $+9,03$ bulan

$\mathrm{PBP}=3$ tahun +9 bulan $+(0,3 \times 30$ hari

$\mathrm{PBP}=3$ tahun +9 bulan +9 hari

Dengan demikian dapat diketahui bahwa waktu kembalinya investasi yang dikeluarkan perusahaan adalah selama 3 tahun 9 bulan 9 hari dengan Net Benefit sebesar Rp. 75.746.160

Dari perhitungan di atas menunjukkan bahwa waktu kembalinya investasi yang dikeluarkan perusahaan lebih cepat daripada target umur perusahaan yang di tetapkan yaitu selama 10 tahun dan masa pinjaman bank yaitu 3 (tiga) tahun dengan demikian dapat lebih memberi keyakinan lagi dalam mengambil keputusan bagi pemilik modal untuk mendirikan usaha Butik Busana Lady Center.

\section{Analisis Break Even Point Period (BEPP)}

Agar lebih jelas lagi selain menghitung menggunakan Pay Back Period (PBP) Butik Busana Lady Center menganalisis menggunakan rumus Break Even Point Period (BEPP). BEPP bertujuan untuk mengetahui kapan perusahaan tidak mengalami keuntungan dan tidak mengalami kerugian.

Tabel 4.9

Perhitungan Break Even Point Period Rencana Usaha Butik Busana Lady Center

\begin{tabular}{|c|c|c|c|c|c|c|}
\hline $\begin{array}{c}\text { Tahun } \\
\text { Ke } \\
\text { (1) }\end{array}$ & $\begin{array}{l}\text { Benefit } \\
\text { (RP) } \\
(2)\end{array}$ & $\begin{array}{l}\text { Cost } \\
\text { (RP) } \\
(3)\end{array}$ & $\begin{array}{l}\text { Net Benefit } \\
\qquad \begin{array}{l}\text { (RP) } \\
\text { (4) }(2-3)\end{array}\end{array}$ & $\begin{array}{l}\text { Benefit } \\
\text { Kumulatif } \\
\text { (RP) }\end{array}$ & $\begin{array}{l}\text { Cost } \\
\text { Kumulatif } \\
(\text { RP) }\end{array}$ & \\
\hline 0 & - & 189.969 .000 & $(189.969 .000)$ & - & 189.969 .000 & \\
\hline 1 & 287.700 .000 & 250.320 .000 & 37.380 .000 & 287.700 .000 & 440.289 .000 & \\
\hline 2 & 302.085 .000 & 262.836 .000 & 39.249 .000 & 589.785 .000 & 703.125 .000 & Cost $>$ Benefit \\
\hline 3ТВ-1 & 332.293 .500 & 275.977 .800 & 56.315 .700 & 922.078 .500 & 979.102 .800 & \\
\hline $4 \mathrm{~TB}$ & 365.522 .850 & 289.776 .690 & 75.746 .160 & 1.287 .601 .350 & 1.268 .879 .490 & Benefit $>$ Cost BEPP \\
\hline 5 & 402.075 .135 & 318.754 .359 & 83.320 .776 & 1.689 .676 .485 & 1.587 .633 .849 & \\
\hline 6 & 462.386 .405 & 366.567 .513 & 95.818 .892 & 2.152 .062 .890 & 1.954.201.362 & \\
\hline 7 & 554.863 .686 & 421.552 .640 & 133.311 .046 & 2.706 .926 .576 & 2.375 .754 .002 & \\
\hline 8 & 665.836 .424 & 484.785 .536 & 181.050 .888 & 3.372 .763 .000 & 2.860 .539 .538 & \\
\hline 9 & 832.295 .529 & 581.742 .643 & 250.552 .886 & 4.205.058.529 & 3.442 .282 .181 & \\
\hline 10 & 1.040 .369 .412 & 698.091 .171 & 342.278 .241 & 5.245.427.941 & 4.140.373.352 & \\
\hline$\sum$ & 5.245 .427 .941 & 4.140 .373 .352 & 1.105.054.589 & 22.459 .080 .271 & 19.942.149.574 & \\
\hline
\end{tabular}

Sumber : Data Diolah 2018

Berdasarkan perhitungan pada Tabel 4.9 diatas dapat diketahui bahwa dari tahun ke 0 (nol) sampai dengan tahun ke 3 (tiga) cost masih lebih besar dibandingkan dengan benefit. Untuk itu tahun ke 1 (satu) sampai ke 3 (tiga) disebut sebagai tahun sebelum terjadinya Break Even Point Period (BEPP). Pada tahun ke 4 (empat) 
diketahui benefit telah lebih besar dari pada cost yang berarti bahwa telah terjadi Break Even Point Period (BEPP) atau terjadinya titik pulang pokok dimana perusahaan tidak mendapatkan keuntungan dan juga tidak mengalami kerugian.

Untuk tahun ke 0 (nol) cost kumulatif diperoleh dari cost investasi hal ini dikarenakan tahun ke 0 (nol) masih dari cost investasi diawal. Kemudian setelah melakukan perhitungan tersebut maka dapat menghitung dengan menggunakan rumus Break Even Point Period sebagai berikut :

$\underline{\Sigma}$

bulan

$$
\begin{aligned}
& \text { BEPP }=3 \text { Tahun }+1,87 \text { bulan } \\
& \text { bulan } \\
& =3 \text { Tahun }+1 \text { bulan }+(0,87 \times 30 \text { hari }) \\
& =3 \text { Tahun }+1 \text { bulan }+26 \text { hari }
\end{aligned}
$$

Berdasarkan perhitungan diatas, Dengan demikian waktu untuk mendapatkan BEPP yang diperlukan oleh Butik Lady Center relatif lebih cepat yaitu 3 tahun 1 bulan 26 hari, dari terget umur perusahaan yang ditetapkan selama 10 tahun dengan peminjaman modal pada pihak Bank selama 3 tahun. Hal ini berarti dapat lebih meyakinkan lagi bagi pemilik modal didalam mengambil keputusan untuk mendirikanusaha Butik Busana Lady Center.

\section{Analisis Kualitatif}

Analisis kualitatif dilakukan dengan cara menganalisis aspek-aspek dalam studi kelayakan bisns, seperti :

\section{Aspek Teknis}

Lokasi usaha Butik Lady Center direncanakan berada di Jalan Jendral Ahmad Yani No.189, Sidoharjo Pringsewu Utara Kabupaten Pringsewu. Pemilihan lokasi berdasarkan pada lokasi yang strategis, seperti : 1) Lokasi berada di pusat Kabupaten Pringsewu dan mudah dijangkau oleh para konsumen, dilewati oleh angkutan umum sehingga menunjang konsumen untuk dapat berkunjung, 2) Lokasi dekat dengan beberapa instansi/lembaga baik negeri maupun swasta. Selanjutnya untuk akses transportasi baik umum maupun pribadi juga terpenuhi untuk menuju lokasi butik maupun untuk mendapatkan pasar yang potensial yang direncanakan yaitu sekolah/instansi/lembaga baik negeri maupun swasta yang ada di Kabupaten Pringsewu.

\section{b. Bangunan}

Bangunan yang akan dipakai adalah bangunan ruko satu lantai dengan luas tanah $8 \mathrm{~m} \times 12 \mathrm{~m}$ atau $96 \mathrm{~m}^{2}$. Bangunan ini memiliki 3 ruangan yang akan dijadikan, ruang produksi (tempat berjualan) kamar mandi dan tempat sholat. Area parkir yang disediakan cukup luas yaitu $8 \mathrm{~m}$ x $6 \mathrm{~m}$ atau $42 \mathrm{~m}^{2}$ bisa menampung sekitar 2 mobil dan 6 motor dan dapat digambarkan dalam bentuk layout.
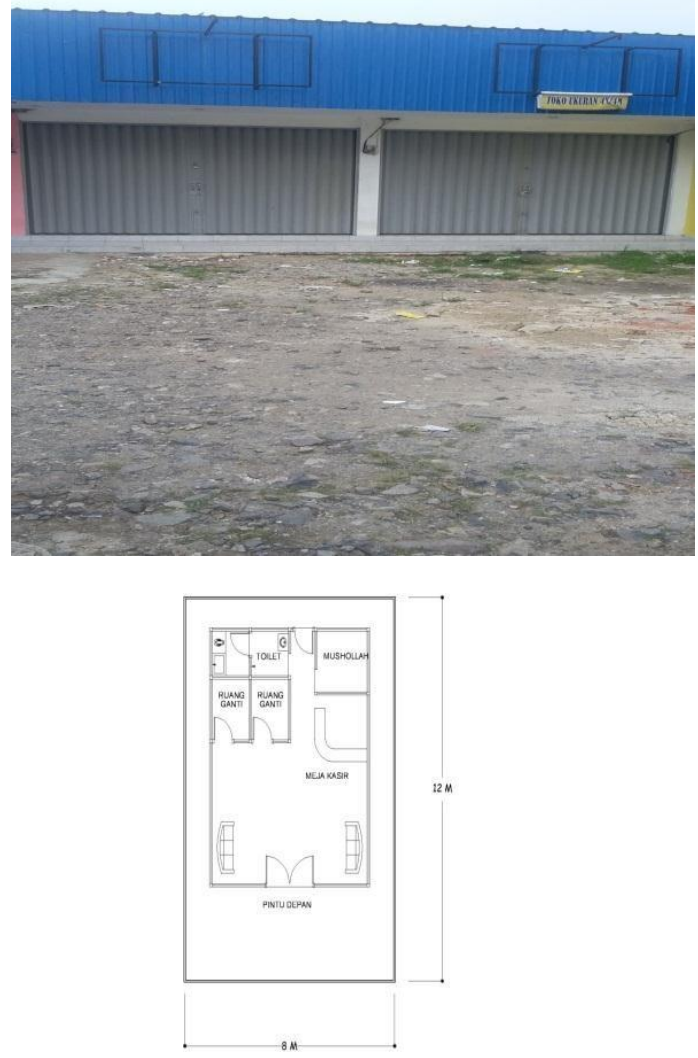
c. Mesin, Peralatan, Perlengkapan dan Fasilitas

Mesin, peralatan dan perlengkapan Butik yang digunakan perusahaan ini adalah sebagai berikut :

1) Mesin/Peralatan terdiri dari :

a) Mesin Barcode. b) Mesin Kasir. c) 2 unit Laptop ASUS PRO P453MA
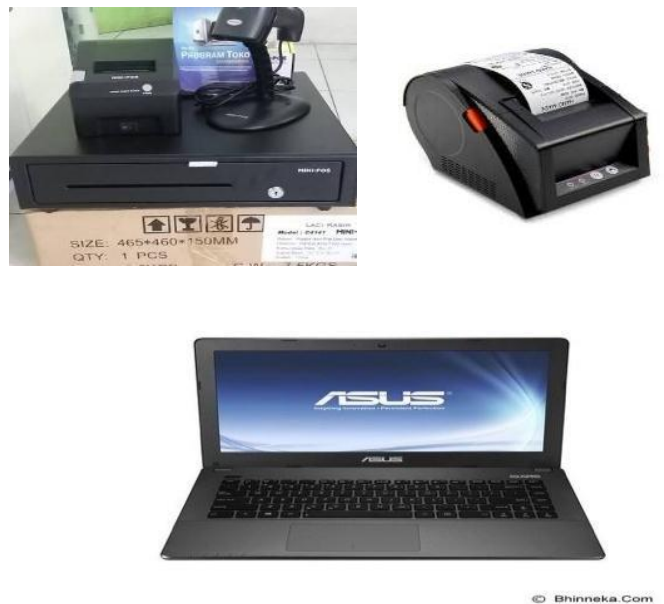

2) Perlengkapan

Perlengkapan adalah prasarana penunjang didalam kegiatan proses produksi dan operasional usaha. Perlengkapan yang digunakan dalam usaha ini adalah :

a) 1 unit Meja Kantor Jenis Expo MT 3001, 2 unit Kursi Troller Ergosit Tira dan 2 unit sofa panjang. b) 10 lusin Gantungan Baju. c) 50 buah Manekin. d) 3 unit Etalase. e) Dispenser Miyako dan galon Aqua. f) 4 unit Cermin Dinding. g) Alatalat Kebersihan seperti : sapu , alat pel, pembersih kaca dan kotak sampah.
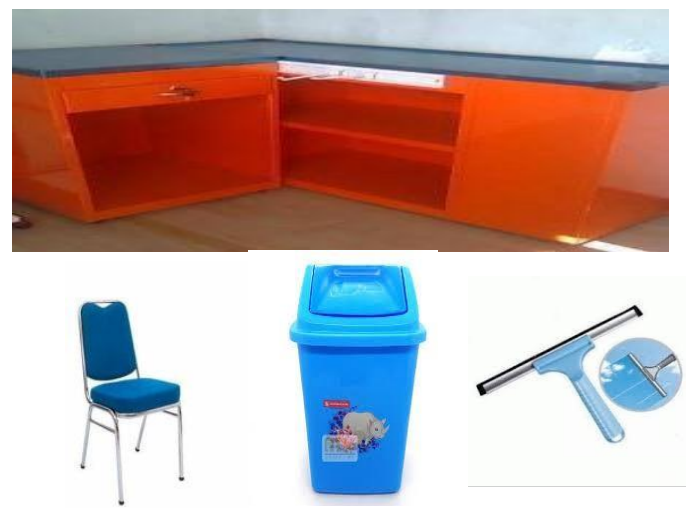
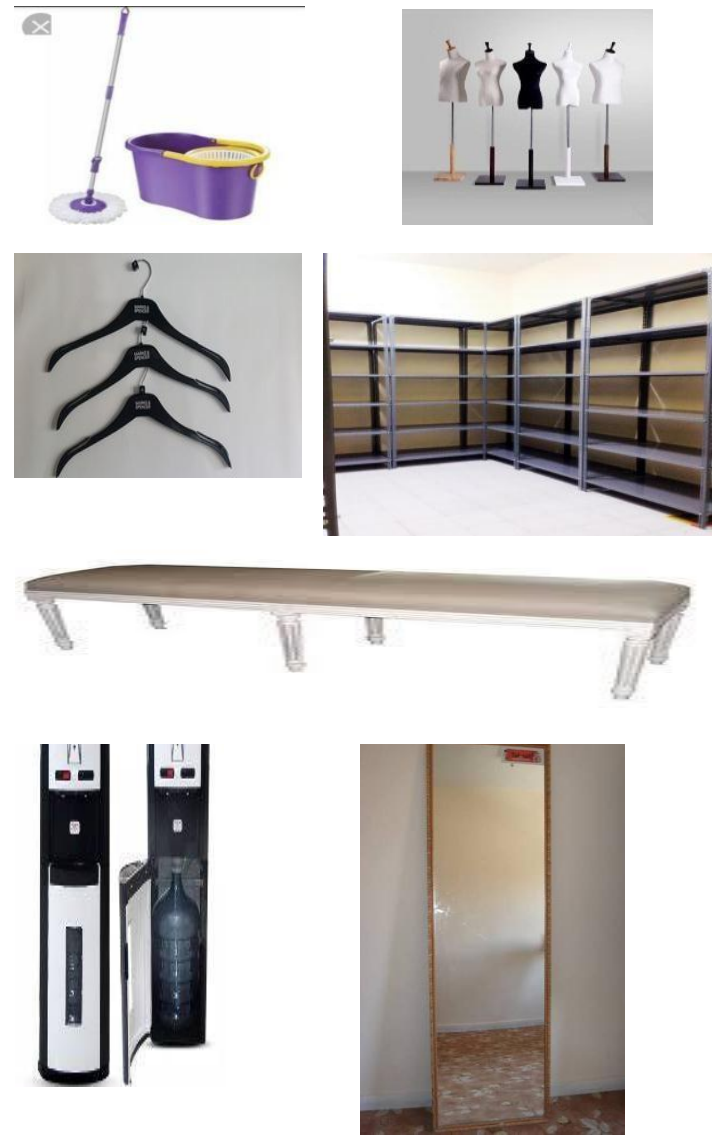

3) Fasilitas

Faslitas yang digunakan antar lain :

a) 1 unit Genset Honda. b) 2 unit CCTV Portable. c) 1 unit AC Samsung. d) 6 unit Lampu LED 5watt. e) Papan nama Neon Box
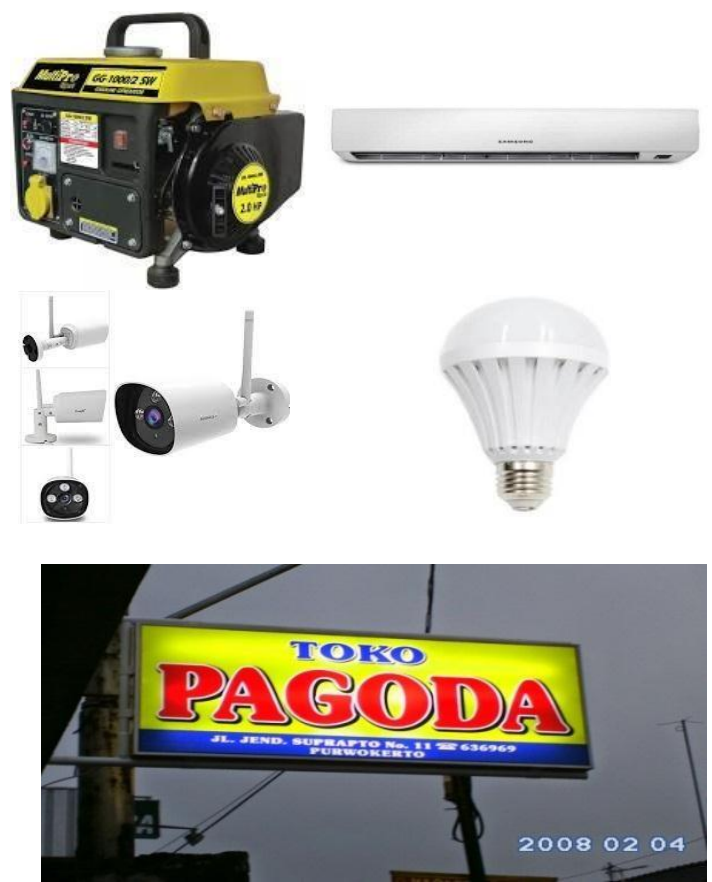


\section{Aspek Pasar dan Pemasaran}

a. Pasar

Pasar yang dituju sudah disegmentasikan dari beberapa faktor antara lain : Aspek Geografis memilih konsumen yang berada di sekitar Pringsewu. Aspek Demografis yang menjadi target pasarnya yaitu kaum wanita dan usia dari remaja hingga dewasa, dan Aspek perilaku yaitu pengetahuan masyarakat tentang trend busana modern semakin berkembang. pasar yang dituju dapat berasal segala lapisan masyarakat baik kalangan menengah maupun atas yang membutuhkan produk ini. Berdasarkan hasil observasi pemintaan akan produk Busana di Pringsewu relatif tinggi dengan demikian Butik Busana Lady Center dapat menjadi alternatif pilihan Butik dengan harga dan lokasi yang mudah dijangkau bagi masyarakat Pringsewu .

b.Pemasaran

Strategi pemasaran yang dipakai adalah 4P (Product, Price, Place/Distribution, dan Promotion). Rencangan strategi pemasaran yang akan dilaksanakan adalah:
a) Product
b) Price

Tabel 4.10 Daftar Rencana Harga Produk Butik Lady Center

\begin{tabular}{|c|c|}
\hline Jenis Produk & $\begin{array}{l}\text { Harga } \\
(\mathrm{RP})\end{array}$ \\
\hline $\begin{array}{l}\text { Gamis } \\
\text { Gamis Brukat } \\
\text { Atasan } \\
\text { Kaos } \\
\text { Tunik } \\
\text { Kemeja } \\
\text { Cardigan } \\
\text { Jaket } \\
\text { Boomber } \\
\text { Daster } \\
\text { Sweter } \\
\text { Celana Jeans } \\
\text { Celana denim } \\
\text { Celana Joger } \\
\text { Celana Hotpents } \\
\text { Celana Dasar } \\
\text { Celana training } \\
\text { Celana Kulot } \\
\text { Rok Span Dasar } \\
\text { Rok Duyung } \\
\text { Rok Flare jeans } \\
\text { Rok Flare Skirt } \\
\text { Rok Tutu Skrikt } \\
\text { Rok Long Skrikt }\end{array}$ & $\begin{array}{r}250.000 \\
350.000 \\
95.000 \\
50.000 \\
120.000 \\
85.000 \\
85.000 \\
150.000 \\
120.000 \\
125.000 \\
85.000 \\
170.000 \\
150.000 \\
120.000 \\
75.000 \\
85.000 \\
75.000 \\
110.000 \\
85.000 \\
100.000 \\
120.000 \\
85.000 \\
100.000 \\
98.000\end{array}$ \\
\hline
\end{tabular}

Sumber : Data Diolah (2018)

\section{c) Place/Distribution}

Saluran distribusi yang digunakan oleh Butik Lady Center ini adalah sebagai berikut :

ButikLadyCenter $\longrightarrow$ Konsumen yaitu menggunakan saluran distribusi secara langsung yaitu dari produsen langsung ke konsumen.

d) Promotion

Kegiatan promosi yang akan dilakukan oleh Butik Lady Center 
adalah dengan melakukan Bauran Promosi yang terdiri dari :

a. Periklanan (advertising), dengan menggunakan media cetak yaitu membuat banner yang dipasang ditempat-tempat keramaian atau dipinggir jalan yang banyak dilalui orang. Selanjutnya dengan memanfaatkan media sosial yaitu dengan membuat web perusahaan, dan media sosial (Facebookdan Instagram).

b. Publisitas/ Hubungan Masyarakat (Publicity/Public Relation)

yaitu promosi dilakukan dengan cara melakukan memberikan give away dan potongan harga pada saat tertentu. c. Strategi Kompetitif

Strategi kompetitif yang digunakan oleh Butik Lady Center adalah dengan menempatkan posisi kompetitif perusahaan sebagai Pengikut Pasar dengan cara belajar dan mengambil manfaat dari pemimpin pasar seperti : penyempurnaan dan pengembangan produk, penggunaan saluran distribusi dan strategi usaha lainnya.

\section{Aspek Yuridis.}

Bentuk badan usaha Butik Lady Center ini adalah perusahaan perseorangan, dengan melengkapi bukti diri KTP, NPWP pemilik, Tanda Daftar Perusahaan (TDP) serta jenis-jenis izin usaha. Adapun jenisjenis izin usaha yang diperlukan antara lain Surat Keterangan Usaha (SKU), Surat Izin Usaha Perdagangan (SIUP), Tanda Daftar Perusahaan (TDP), Surat Izin Gangguan $(\mathrm{HO}=$ Hinder Ordonantie $)$, Tanda Daftar Industri (TDI).

\section{Aspek Birokrasi.}

Untuk mendirikan atau melaksanakan rencana usaha harus mendapatkan izin dari pemerintah. Berdasarkan jenis usaha, Butik Lady Center harus memiliki beberapa macam jenis surat izin yaitu Surat Keterangan Usaha (SKU), Surat Izin Usaha Perdagangan (SIUP), Tanda Daftar
Perusahaan (TDP), Surat Izin Gangguan (HO), Tanda Daftar Industri (TDI). Untuk mendapatkan izin-izin tersebut, diperlukan proses atau cara dalam membuat izin tersebut. Syarat pembuatan SKU :Surat Pengantar RT/RW, Kartu Tanda Penduduk (KTP) yang masih berlaku (Asli dan Fotokopi), Kartu Keluarga (KK) fotokopi, Surat Pernyataan/ Permohonan.

\section{Aspek Manajemen dan MSDM.}

Usaha Butik ini merupakan perusahaan perseorangan yang dimiliki hanya oleh satu orang pemilik, satu orang manager dan beberapa karyawan. Perencanaan usaha ini memerlukan beberapa karyawan yang memiliki keahlian dan spesialisasi dibidangnya masing-masing. Dalam pelaksanaan kegiatan usaha ada struktur organisasi yang menunjukkan pembagian pekerjaan berikut jumlah karyawan yang meliputi:

Menajer : : 1 orang Kasir $\quad: 1$ orang

Karyawan bagian pelayanan : 1 orang Untuk menyusun struktur organisasi perlu terlebih dahulu dibuat pembagian tugas bagian-bagian yang ada didalam struktur organisasi. Rancangan struktur organisasi Butik ini dapat dilihat pada Gambar 4.6.

Gambar 4.6 Rancangan Struktur Organisasi Lady Center

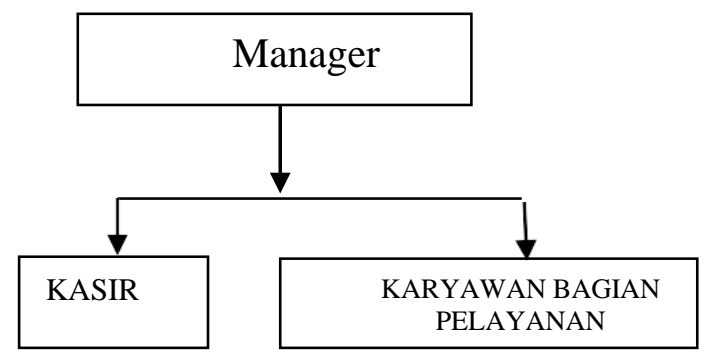

6. Aspek Ekonomis.

Dengan adanya Butik Lady Center yang akan dapat memberikan kemudahan bagi masyarakat Pringsewu untuk mencari tempat berbelanja produk busana wanita dengan model yang trendi dan tempat yang nyaman. Juga dapat mensejahterakan masyarakat dengan membuka lapangan 
pekerjaan, menciptakan peluang pendapatan bagi pihak yang berkaitan dengan proyek baik langsung maupun tidak langsung diantaranya jasa parkir, para industri fashion,tukang jahit serta memberikan manfaat bagi pemerintah melalui pajak yang dikenakan pada perusahaan sehingga dapat menunjang pembangunan daerah Pringsewu lebih baik.

\section{Aspek Lingkungan.}

\section{Lingkungan Industri}

Ancaman masuknya pendatang baru Masuknya usaha Butik sebagai pendatang baru akan menimbulkan implikasi bagi usaha-usaha yang sejenis dan sudah ada. Dengan adanya pendatang pendatang baru maka mempengaruhi unsur-unsur lain seperti : kapasitas produksi bertambah, terjadinya perebutan pangsa pasar, perebutan sumber daya produksi yang terbatas, naiknya tingkat persaingan, dan tarif harga yang tidak stabil.

2. Lingkungan Pendidikan

Butik Lady Center berada disekitar lingkungan pendidikan dimana dekat dengan sekolah, dan instansi/ lembaga umum maupun swasta sehingga masyarakat dengan mudah menjangkau butik setelah selesai sekolah maupun selesai bekerja.

3. Lingkungan hidup

Hal-hal yang dilakukan oleh Butik Lady Center dalam mengelola lingkungan adalah Menjaga kebersihan lingkungan butik karena Butik Lady Center menghasilkan limbah plastik dan kardus yang dapat merugikan masyarakat. Hal ini dilakukan secara rutin (continue) setiap hari untuk menghindari terjadinya penumpukan sampah dan debu di lokasi usaha. Jika sampai terjadi penumpukan, maka akan mempengaruhi minat para pelanggan untuk datang dan memberikan order ke tempat.

\section{KESIMPULAN DAN SARAN Kesimpulan}

Berdasarkan hasil analisis kuantitatif dan kualitatif yang telah dilakukan maka dapat diuraikan sebagai berikut :

1. Analisis Kuantitatif

a. Kriteria Investasi

Berdasarkan hasil Analisis Kriteria Investasi dengan jumlah Net Present Value (NPV) sebesar Rp 467.412.569 hal ini menunjukan NPV $>0$ (nol). Net Benefit Cost Ratio (Net B/C) sebesar 1,19 ini menunjukan bahwa Net B/C

$>1$. Dan Internal Rate of Return (IRR) sebesar 35,83\%. Berarti IRR > dari tingkat bunga yang berlaku (10\%). Berdasarkan analisis kriteria investasi dinyatakan layak untuk untuk dilaksanakan (go) karena telah memenuhi standar kelayakan yang berlaku pada analisis kriteria investasi.

b. Pay Back Period (PBP)

Berdasarkan Analisis Pay Back Period (PBP) diketahui bahwa waktu yang dibutuhkan proyek ini untuk mengembalikan modal keseluruhan adalah selama 3 tahun 9 bulan 9 hari. Hal ini berarti waktu yang dibutuhkan untuk mengembalikan modal lebih cepat dari pada umur proyek yang umurnya 10 tahun. Dengan demikian rencana pendirian usaha ini akan mendatangkan keuntungan Butik Lady Center karena layak untuk dijalankan ( $g o$ ).

Berdasarkan analisis pay back period dinyatakan layak dalam arti waktu pengembalian modal.

\section{c. Break Event Point Period (BEPP)}

Berdasarkan analisis Break Event Point

Period (BEPP) diketahui waktu yang dibutuhkan Butik Lady Center untuk dapat memperoleh keuntungan bersih pada saat Break Event Point Period terjadi yaitu dalam waktu 3 tahun 1 bulan 26 hari. Waktu yang dibutuhkan untuk mendapatkan keuntungan relatif lebih cepat dibandingkan dengan umur proyek (10 tahun). Dengan demikian rencana pendirian usaha ini akan mendatangkan keuntungan bagi Butik 
Lady Center karena layak untuk dijalankan $(\mathrm{go})$.

Berdasarkan analisis break event point period dinyatakan layak dalam arti waktu dalam memperoleh keuntungan bersih.

\section{Analisis Kualitatif}

Berdasarkan Analisis kualitatif, yaitu berdasarkan aspek teknis, aspek pasar dan pemasaran, aspek yuridis, aspek pemerintah dan birokrasi, aspek manajemen, aspek ekonomis, serta aspek lingkungan bahwa rencana usaha Butik Lady Center layak untuk dilaksanakan (go).

Secara keseluruhan berdasarkan hasil analisis secara kuantitatif maupun kualitatif dapat disimpulan bahwa rencana usaha Butik Lady Center layak untuk dilaksanakan $(g o)$.

\section{Saran}

Berdasarkan kesimpulan yang telah diperoleh diatas, maka penulis memberi saran sebagai berikut :

a. Rancangan pendirian usaha butik ini agar dapat segera merealisasikan karena rencana usaha tersebut layak untuk dilaksanakan.

b. Untuk memenuhi kebutuhan dana maka dapat langsung mengajukan permohonan pinjaman kepada bank agar dapat segera menjalankan/mendirikan rencana usaha tersebut.

c. Walaupun sudah dinyatakan layak, usaha Butik Lady Center ini harus tetap ada pengawasan dalam pelaksanaan dengan berpedoman pada analisis kelayakan bisnis.

\section{DAFTAR PUSTAKA}

Abdullah, Ma'aruf M. 2017. Studi Kelayakan Bisnis.Yogyakarta. CV.ASWAJA PRESSINDO.
Ibrahim, Yacob. 2009. Studi Kelayakan Bisnis. Jakarta: PT.RINEKA CIPTA.

Kasmir, dan Jakfar. 2012. Studi Kelayakan Bisnis. Jakarta. Kencana Prenada Media Group.

Kasmir, dan Jakfar. 2013. Studi Kelayakan Bisnis. Edisi Revisi. Jakarta. Kencana Prenada Media Group.

(online). (2018). Contoh Proposal Usaha Butik. Dipetik November 14,2018. Dari http://www.academia.edu/9733 261.

(online). (2017). Pengertian Bisnis. Dipetik November 27, 2017 dari http://id.m.wikipedia.org/wiki/ $\underline{\text { bisnis }}$

(online). (2017). Pengertian Studi Kelayakan Bisnis. Dipetik November 27, 2017 dari http://id.m.wikipedia.org/wiki/ $\underline{\text { studi+kelayakan+bisnis }}$

Saputri, Rindi Dian. 2017.Analisis Studi Kelayakan Kelayakan Rencana Usaha Konfeksi CHAMPION di Bandar Lampung, Skripsi Strata . Fakultas Ekonomi dan Bisnis Universitas Bandar Lampung.

Sanjaya, Nia. 2017. Analisis Studi Kelayakan Rencana Usaha Café MONOKROM di Lampung Selatan, Skripsi Strata 1. Fakultas Ekonomi dan Bisnis Universitas Bandar Lampung.

Sofyan, Iban. 2002. Studi Kelayakan Bisnis. Yogyakarta: Graha Ilmu. 
Suliyanto. 2010. Studi Kelayakan Bisnis. Yogyakarta. CV. Andi Offset.

Sunyoto, Danang. 2014. Studi Kelayakan Bisnis. Yogyakarta. Centre Of Academic Publishing Service.

Umar, Husein. 2009. Studi Kelayakan Bisnis. Edisi 3 Revisi. Jakarta: PT. SUN.

Wulan, Sapmaya.2015.. Buku Bahan Ajar Analisis Kelayakan Bisnis. Universitas Bandar Lampung

Wulan, Sapmaya.2012. Analisis Studi Kelayakan Bisnis Guest House Family Di Bandar Lampung. Jurnal Manajemen dan Bisnis Vol. 3 No.1 Oktober 2012. Penerbit Universitas Bandar Lampung Fakultas Ekonomi Program Studi Manajemen. Bandar Lampung. 